\title{
NOTES
}

\section{LIABILITY OF A SURGEON FOR THE EXTENSION OF AN AUTHORIZED OPERATION}

\section{$\mathrm{T}$}

HAT BODY OF LEGAL MEDICINE which defines the liability of a physician for malpractice, ${ }^{1}$ grounded as it is in the principles of negligence, ${ }^{2}$ is always in a necessary conformity with the prevailing medical standards of due care. ${ }^{3}$ Less responsive to the developments of modern medicine, however, are the rules of law that define the liability of a physician for a technical battery. ${ }^{*}$ The problem is typically raised when a surgeon exceeds the anticipated scope of an authorized operation; and the issue is uniformly resolved in terms of whether or not the circumstances gave rise to an "implied consent" to the extension. ${ }^{5}$ The early common law rigorously required the patient's actual consent to any extension; ${ }^{6}$ but, with the advent of anesthetics, ${ }^{7}$ the courts recast the

\footnotetext{
${ }^{1}$ See, generally, Elweli, Malpractice and Medical Evidence 7-r68 (r886); Cady, Law Relating to Medical Practice: The Doctor's Diagnosis and Treatment of Patients, in Legal Medicine ro8-ig (Gradwohl ed. 1954); Herzog, Medical JurisPRUDENCE c. XIII (I93r); SCHEFFeL, MEDICAL JURISPRUDENCE 82-r67 (r93r); OPPENHEIMER, MEDICAL JURISPRUDENCE 53-IOO (1935).

2 "[T] he word [malpractice] is used more and more frequently by the courts as though synonymous with negligence on the part of the professional attendant." Regan, Medical Malpractice 2 I (I943).

${ }^{3}$ The test of liability generally accepted in actions for malpractice is that a physician must "possess and exercise that reasonable and ordinary degree of learning, skill, and care commonly possessed and exercised by reputable physicians practicing in the same locality." REGAN, op. cit. sulpra note 2, at 15. See Note, I6 U. PITT. L. REV. II3 (1940), for a collection of cases applying this standard. See also LotT and Gray, LaW in Medical and Dental Practice i9-5i (1942); Prosser, Torts 132 (2d ed. 1955); Restatement, Torts $§ 299$, comment d (1934).

- See Prosser, op. cit. supra note $3, \$ 9$; Restatement, Torts $\$ \S$ I 8-20 (r934).

${ }^{5}$ See Restatement, Torts $\$ 54$, comment a (1934); Note, Consent as a Prerequisite to a Surgical Operation, I+ U. CIN. L. Rev. I6I (19+0).

${ }^{\circ}$ Slater v. Baker and Stapleton, 2 WiLs. K.B. 359, 95 Eng. Rep. 860 ( ${ }_{7767}$ ) (dictum) (defendant doctor held liable for rebreaking plaintiff's leg without securing express consent) ; Jackovach v. YocoM, 212 Iowa 914, 927, 237 N.W. 444, 450 (I93I) (dictum).

" "[T] he introduction of anaesthesia into the practice of surgery has modified the application of the common law rule in certain fundamental respects of which the law must take notice." Bennan v. Parsonnet, 83 N.J.L. 20, 22, 83 Atl. 948, 949 (1912).
} 
rule and recognized an implied consent by the patient in the case of "an emergency ... calling for immediate action for the preservation of the life or health of the patient." The usual strict application of this "emergency" doctrine has sometimes led to harsh results; ${ }^{0}$ but a few courts, ${ }^{10}$ in the light of changing surgical practices, ${ }^{11}$ have been inclined not to limit the surgeon strictly to cases of emergency immediately endangering life or health. ${ }^{12}$

The liberalizing effect of these later decisions on the older body of the law, however, has been tempered by a consistent verbal adherence to the "emergency" doctrine. ${ }^{13}$ The courts seem to have broadened the

See also McGuire v. Rix, I 8 Neb. 434, 440, 225 N.W. 120, 123 (1929). It was not until 1846 that anesthetization by ether began to be widely practiced. I ENCYC. BRrT. 862 (1951).

8 The leading case is Mohr v. Williams, 95 Minn. 261, ro4 N.W. 12 (1905), in which the defendant surgeon had advised an operation on the plaintiff's right ear. During the operation, and while the patient was unconscious, the surgeon discovered that the left ear instead was the cause of the plaintiff's complaint and successfully operated on it. The court held the defendant liable for battery on the ground that no emergency justified the extension of the operation. See also Luka v. Lowrie, I7I Mich. 122, I36 N.W. I 106 (1912); Franklyn v. Peabody, 249 Mich. 363, 228 N.W. 68I (1930); McGuire v. Rix, 118 Neb. 434, 225 N.W. 120 (1929). The law review treatment of this point is sparse. Smith, Antecedent Grounds of Liability in the Practice of Surgery, i4 RockY MT. L. REv. 233 (1942); Straub, The Surgeon and the Unconscious Patient, 33 Law Notes 29 (1929); Notes, 26 Mich. L. Rev. 561 (1928), 14 U. CIN. L. REv. I6I (1940), I9 TENN. L. REv. 374 (1946); 26 HARv. L. REV. 9 I (1912).

'For example, in Franklyn v. Peabody, 249 Mich. 363, 228 N.W. 681 (1930), where the plaintiff had submitted to an operation for a stiff finger, the court held the defendant surgeon liable in battery for transplanting a small amount of skin from the plaintiff's thigh to correct a newly discovered adhesion of tendons which was causing the stiffness. Cf. Comment, 22 Y YLE L.J. 243, 246 (1913), where the view is expressed that the "emergency" doctrine should exonerate a physician only when there was a serious and immediate danger of losing life or limb.

${ }^{10}$ See McGuire v. Rix, 1 i 8 Neb. 434, 225 N.W. 120 (1929); Bennan v. Parsonnet, 83 N.J.L. 20, 83 Atl. 948 (19I2). Cf. Barnett v. Bachrach, 34 A.2d 626 (D.C. Mun. Ct. 1943). In particular, two Canadian cases have demonstrated a marked liberality. Marshall v. Curry, 3 D.L.R. 260 (1933); Caron v. Gagnon, 68 Que. S.C. 155 (1939).

11 " $[T]$ he scope of modern surgical operations has been greatly enlarged, and the legal rule applicable thereto extended beyond the emergencies of actual surgery to other matters more or less vitally affecting the patient's welfare. To meet these clinged conditions, the rule of law must, in the interest alike of the patient and the surgeon, be adapted to the changes that have been so wrought. ..." Bennan v. Parsonnet, 83 N.J.L. 20, 24, 83 Atl. 948, 950 (1912).

${ }^{12}$ See $26 \mathrm{MrCH}$. L. REv. 56r, 562 (1928), where such a tendency was noted.

${ }^{13}$ The law review comment sparked by the liberal case of Bennan v. Parsonnet, 83 N.J.L. 20, 83 Atl. 948 (19r2), is significant. Compare Note, 26 MrCH. L. REv. 
scope of a surgeon's privilege by artificially expanding the concept of "emergency" rather than by formulating additional tests of liability. A recent decision by the North Carolina Supreme Court, however, appears to mark a significant departure in this respect. In Kennedy v. Parrott, ${ }^{14}$ where a surgeon was absolved of liability for puncturing ovarian cysts in the course of an appendectomy, ${ }^{15}$ the court frankly recognized the inadequacy of the traditional "emergency" test and refused to define the surgeon's liability in those terms. ${ }^{16}$

This express rejection of the "emergency" test introduces the troublesome problem of devising a new formula by which liability should be determined in the future, ${ }^{17}$ and it is in this respect that the opinion in the Kennedy case is somewhat deficient. In one part of the opinion, the court seems to suggest that the scope of a surgeon's privilege should be measured by the current standards of "good surgery." 18 Under this test, implied consent to an extension would probably be inferred whenever it could be shown that the extension accorded with generally accepted surgical practices. ${ }^{19}$ Perhaps the theoretical justification for this "good surgery" test would be that patients should anticipate all extensions which it is the accepted practice to make ${ }^{20}$ and should ex-

56I (1928), and 96 Sol. J. 20 (1952), with Comment, 22 YALE L.J. 243, 246 (1913), and 26 HARv. L. REv. 91 (1912). See also Barnett v. Bachrach, 34 A. 2d 626, 629 (P.C. Mun. Ct. 1943).

${ }_{14} 243$ N.C. 355 , 90 S.E.2d 754 (1956).

${ }^{15}$ The principal theory of the plaintiff's case was that injury had resulted from the negligence of the defendant. The court first held that the nonsuit of this malpractice claim was proper, and then proceeded to discuss the action for technical battery. Cf. Wells v. Van Nort, 100 Ohio St. 101, 125 N.E. 910 (1919), and Caron v. Gagnon, 68 Que. S.C. 155 (1939), involving similar fact situations.

${ }^{10}$ The court observed that modern changes in surgical technique require a reappraisal of the older rules of liability. 243 N.C. at 360,90 S.E.2d at 758 .

${ }^{17}$ For the best treatment of this problem, see Smith, supra note 8 , wherein the author attempts to categorize the cases and to formulate a satisfactory test of liability for each category.

${ }^{18}$ "In short, where an internal operation is indicated, a surgeon may lawfully perform, and it is his duty to perform, such operation as good surgery demands, even when it means an extension of the operation further than was originally contemplated. ..." 243 N.C. at 363 , 90 S.E.2d at 759.

${ }^{10}$ In the Kennedy case, the court remarked that "it is not amiss to note that the expert witnesses testified that the puucture of the cysts was in accord with sound surgical procedure, and that if they had performed the appendectomy they would have also punctured any enlarged cysts found on the ovaries. "That is the accepted practice in the course of general surgery." " 243 N.C. at 363 , 90 S.E.zd at 760 .

${ }^{20}$ See passage from the Kennedy opinion quoted in note 25 infra. 
pressly prohibit any such extensions to which they would not consent. ${ }^{21}$ However, since it is obvious that patients are generally unaware of prevailing surgical practices, there would be no valid factual basis for this rationale. Instead, it seems that the practical effect of adopting the "good surgery" test as the sole gauge of liability would be to allow the medical profession itself to determine the scope of a surgeon's privilege. This solution of the problem does not seem entirely satisfactory, for there is the distinct possibility that the surgeons, unrestrained by independent legal sanctions, might be impelled by other interests to extend the scope of their privilege without full regard to the individual's right to be secure from any unauthorized bodily contact. ${ }^{22}$ This prospect, in turn, raises the obvious possibility that the patients would ultimately be required to make out a case of malpractice in order to sustain an action for technical battery.

But in addition to the "good surgery" limitation, the Kennedy opinion seems also to suggest that a physician's activities must be confined to "remedying any abnormal or diseased condition in the area of the original incision."23 This definition of the surgeon's privilege, however, may be too mechanical to resolve adequately the wide variety of cases that may arise. On the one hand, it is conceivable that accepted surgical procedure could dictate operations within "the area of original

${ }^{21}$ It is undisputed, of course, that a physician will always be held liable for extending an operation in contravention of his patient's express prohibition. Rolater v. Strain, 39 Okla. 572, 137 Pac. 96 (1913); Markart v. Zeimer, 67 Cal. App. 363, 227 Pac. 683 (1924). But see Beatty v. Cullingworth, Q.B. Unreported, 44 CENT. L.J. 153 (1896), where the court "recognized the binding force of an express prohibition but commented the patient out of court by his misleading charge." Smith, supra note 8, at 235. Se also i4 U. CIN. L. REv. 161, 166-67 (1940).

${ }^{22}$ See text to note 30 infra. A distinction must be noted between accepting the prevailing practices of the medical profession to determine how far a surgeon may extend an operation without the express consent of the patient, see note 19 supra, and accepting those practices to determine whether a surgeon has exercised reasonable skill and care in performing an admittedly authorized operation. See note 3 supra. As for the latter criteria, physicians are always driven by competition, as well as by the best interests of their patients, to establish the highest practicable standard of skill and care. But as for the former criteria, there are factors that may encourage the acceptance of practices which too liberally invade the individual's right of bodily security. The least of these, perhaps, is an acquisitive spirit on the part of the medical profession. Cf. Mulloy v. Hop Sang, I West. Weekly R. 714 (Sup. Ct. Alberta 1935) (suit by surgeon for fee after extended operation). More important would be the inclination of the surgeon to perform any additional operation which, from a purely medical standpoint, would be in the interest of the patient's health-e.g., the removal of a wart during the course of an appendectomy.

${ }_{23}^{243}$ N.C. at 362,90 S.E.2d at 759 (1956). 
incision" which should be prohibited in the absence of the patient's express consent. And, on the other hand, it might frequently be necessary for a surgeon to extend the "area of original incision" in order to correct the condition of which the patient was complaining.

Accordingly, there has been advanced one further test which may be the most satisfactory in several respects. ${ }^{24}$ It would seem entirely proper to allow a surgeon to extend the scope of an operation in any manner necessary to relieve the patient of his presenting complaint. ${ }^{25}$ Such a test would rest on the realistic assumption that doctors are ordinarily engaged to give the patient symptomatic relief-not to perform a specifically defined operation. ${ }^{26}$ In addition, it is becoming increasingly well recognized that preoperative diagnosis cannot completely disclose the causes of a patient's affliction. ${ }^{27}$ Even in the application of this "symptomatic" test, however, it is obvious that some precautions must be observed. ${ }^{28}$ When a minor operation is contemplated, a surgeon should certainly be required at some point to refrain from greatly increasing the total risk involved, or from denying his patient the future use of a functional part of the body. ${ }^{29}$ This point beyond which the surgeon should not be allowed to proceed, even to alleviate the presenting complaint, is not at all defined by the "symptomatic" test; yet this is obviously the very question that the test was framed to answer.

This latter observation suggests that perhaps the "good-surgery," the "area-of-original-incision," and the "symptomatic" tests should never be

${ }^{24}$ Smith, supra note 8 , at $242-45$.

${ }^{25}$ There is some suggestiou of this test by the court in the Kennedy case: "And ordinarily a surgeon is justified in believing that his patient has assented to such operations as approved surgery demands to relieve the affiction with which he is sulfering." 243 N.C. at 363 , 90 S.E.2d at 760 [emphasis added]. In support of this proposition the court cites Dicenzo v. Berg, 340 Pa. 305, I6 A.2d I5 (1940) (dictum).

${ }^{20}$ This particular aspect of the physician-patient relationship has, at various times, been recognized by the courts. In the Kennedy case, for example, the court said: "Usually there is no specification or particularization as to what the physician shall do." 243 N.C. at 360 , 90 S.E.2d at 757 . See also Bennan v. Parsonnet, 83 N.J.L. 20, 23, 83 Atl. 948, 949 (I912) ; Barnett v. Bachrach, 34 A.2d 626, 629 (D.C. MunCt. 1943). But see Hively v. Higgs, 120 Ore. 588,253 Pac. 363 (1927), where the court, in holding a surgeon liable for performing a tonsillectomy during a nasal resection, observed that the patient had given the surgeon no general directions to do whatever necessary for the relief of the patient's ailments.

${ }^{27}$ See, e.g., Bennan v. Parsonnet, 83 N.J.L. 20, 24, 83 Atl. 948, 950 (1912); Smith, supra note 8 , at 243 .

${ }^{28}$ Limitations on this test have been suggested by the only writer yet to expound it in any detail. Smith, supra note 8 , at 245 .

${ }^{30}$ See text to notes 34 and 35 infra. 
completely determinative of a surgeon's liability. Instead, these tests seem only to reflect certain considerations which the courts recognize as relevant and which are relatively easy to articulate. Furthermore, the inadequacy of these tests indicates the presence of more fundamental considerations that are harder to epitomize into formulas. These more fundamental considerations concern the underlying conflict between the right of an individual to be secure from any unauthorized interference with his person ${ }^{30}$ and the interest of the public in "encouraging selfreliant surgeons."31 Since a patient can always protect his right of bodily security by expressly prohibiting any extension of his operation, ${ }^{32}$ it appears that he should not be protected at the expense of the public interest unless the battery he has suffered is of some practical consequence. $^{33}$ One practical consideration is the fact that any extension

$$
\S 9 \text {. }
$$

${ }^{30}$ See Restatement, Torts $\$ \$$ I 8-2o (1934); Prosser, op. cit. sapra note 3,

31 "The law should encourage self-reliant surgeons to whom patients may safely entrust their bodies, and not men who may be tempted to shirk from duty for fear of a law suit." Barnett v. Bachrach, 34 A.2d 626, 629 (D.C. Mun. Ct. 1943), quoted in the Kennedy opinion. 243 N.C. at 361,90 S.E.2d at 758 .

One commentator has suggested that there is a "public interest in the preservation of life and health [which] gives weight to the argument that the surgeon should be allowed to use his discretion." 26 Harv. L. REv. 91 (1912), noting Bennan v. Parsonnet, 83 N.J.L. 20, 83 Atl. 948 ( 1912 ). This statement of the countervailing public interest seems definitely misleading. The public does have an interest in encouraging surgeons to take steps necessary for the preservation of life and health, since the majority of patients would prefer that such steps be taken. But the public does not have an interest in preserving the life of an individual who would prefer to die rather than undergo an operation. This distinction, though nice, is crucial. If it is not observed, then one might conclude that the express prohibition of an extension of an operation is against public policy.

${ }^{32}$ See cases cited in note 2 stipra.

${ }^{33}$ This general proposition recognizes that the extent of protection which the law should accord any interest-individual, public, or social-should be measured not only by the nature of that interest, but also by the extent to which those who claim that interest can protect it without the aid of the law. Cf. Pound, INTronuction to THE Philosophy of THE LAW (1922); Pound, A Survey of Social Interests, 57 Harv. L. REv. I (1943). Analyzed in these terms, then, the problem of defining a surgeon's liability for technical battery is essentially a question of determining whether the burden of affirmatively instructing the surgeon should rest upon those who wish lim to exercise his discretion broadly or upon those who wish to restrict his activity. The practical consequence of imposing this burden on the former group would be to deprive most patients of the benefits of good surgery. See note 31 supra. Therefore, it seems that it should be incumbent upon those individuals who wish to claim their right of freedom from bodily contact to take affirmative action, unless the injury which would result from the violation of that right is actual harm. See text to notes 34 and 35 infra. 
of an operation involves a greater or less degree of risk. To the extent, therefore, that the risk factor is appreciable, an extension will constitute more than an invasion of a merely abstract right of personal inviolability; it will deprive the patient of the opportunity of choosing whether or not to assume the risk involved. ${ }^{34}$ Another such practical aspect appears when the extended operation affects the use of a functional part of the body. For example, absent the risk factor, a patient ordinarily could raise only a technical complaint against the removal of a tumor or a diseased appendix; but he sustains a very real loss when deprived of his vocal cords or reproductive organs. ${ }^{35}$

In the final analysis, then, these cases seem to involve a question of weighing the risk and inconvenience of delaying an extension against the risk and disabling effect of an immediate extension. Surely the courts should still approve any extension which would have been justifiable under the old emergency test, ${ }^{36}$ but beyond that there can be no definitive guide other than that made available by a sensitive appraisal of the above considerations.

\footnotetext{
${ }^{34}$ See Smith, supra note 8, at 242-243.

${ }^{35}$ But cf. Hively v. Higgs, 120 Ore. 588, 590, 253 Pac. 363,365 (1927), where the court said that the law presumes that every organ has some function to perform in maintaining the body in sound health, and that this presumption is not overcome by showing that medical science has not ascertained that function.

${ }^{30}$ See, e.g., Jackovach v. Yocom, 212 Iowa 914, 237 N.W. 444 (193I); Luka v. Lowrie, 171 Mich. 122, 136 N.W. I106 (1912).
} 